\title{
Who is LISA?
}

\author{
Donna Thompson ${ }^{1, \star}$ \\ ${ }^{1}$ Harvard-Smithsonian Center for Astrophysics, 60 Garden St., Cambridge, MA, USA
}

\begin{abstract}
The field of library science is always changing. Even professional library organizations have conducted studies about changing the name of the profession. All of the attendees of the LISA meeting are involved in Library and Information Sciences in Astronomy and we represent a number of different organizations and professions. In crafting a white paper about the profession, an ethnographic study of the field was proposed with the research reported on at the LISA meeting. The research methods include an online survey and in person interviews with various members of the community. We hope to identify trends, differences and a road map for the future.
\end{abstract}

\section{Introduction}

At the 2015 International Astronomical Union General Assembly (IAU) meeting, and specifically at the focus group meeting for Scholarly Publication in Astronomy: Evolution or Revolution?, librarians, scientists, editors and others involved in the distribution of astronomy literature recommended that a white paper documenting the roles and responsibilities of astronomy libraries be written. The LISA meetings involve a number of astronomy librarians. In this paper I am going to present some information about the history and attendance at the LISA meetings. This information will be helpful in the preparation of the white paper for the IAU.

\section{Who are astronomy librarians?}

Astronomy librarians work at observatories, colleges, universities, government agencies and other research institutions. Frequently, astronomy librarians have responsibilities for other topics in addition to astronomy and there are few librarians who focus solely on astronomy. This being said there are at least five professional groups that represent astronomy librarians. Each organization is different but there can be overlap in membership as some astronomy librarians may belong to more than one group.

The International Astronomical Union (IAU) has a working group on Information Professionals. The working group was previously named the working group on libraries and was officially recognized by the IAU in 1991. This group meets every 3 years at the IAU General Assembly. The aim of this group is to foster communication between scientists, librarians and other members of the astronomical community. The membership of the working group reflects the diversity of the parties involved. One of the strengths of this group is that the membership is international.

^e-mail: dthompson@cfa.harvard.edu ORCID: 0000-0001-6870-2365 
The Physics-Astronomy-Mathematics (PAM) Division of the Special Libraries Association is an active group of librarians who meet yearly.[4] Membership is typically about 150 to 200 librarians representing the three major fields of the Division. The PAM Division maintains an active website and listserv that are great resources for the astronomy library community. Membership of the PAM Division is mostly North American although it is open to international participation.

The Forum for Research Sharing in Astronomy and Astrophysics (FORSA) is an active group of astronomy librarians in India. The focus of this group is for sharing and streamlining resources for the many universities, observatories and research institutions in India.

The Astronomy Librarians of Hawaii Association (ALOHA) serves the community of Hawaii with its large number of telescopes. The librarians in this group meet to foster communication about events in their libraries and institutions.

\section{History of the LISA meetings}

The first LISA meeting was held in July 1988 in Washington D.C. just before the XXth General Assembly of the IAU. [1] The IAU provided some financial support and also served as a catalyst to bring the scientific and library communities together. (See Corbin and Grothkopf, 2006, for more complete information.[2]) To date there have been eight LISA meetings in total. The aim is to have a meeting every three to four years in a different location so that interested individuals from different parts of the world can participate. The average attendance for the eight meetings has been 106. (See figure 1.) At the conclusion of LISA VIII it was announced that a number of libraries have expressed interest in hosting LISA IX and hopefully this will happen.

\section{LISA Meetings}

- Washington, DC, USA July 1988

- Garching, Germany May 1995

- Tenerife, Spain April 1998

- Prague, Czech Republic July 2002

- Cambridge, MA, USA June 2006

- Pune, India February 2010

- Naples, Italy June 2014

- Strasbourg, France June 2017

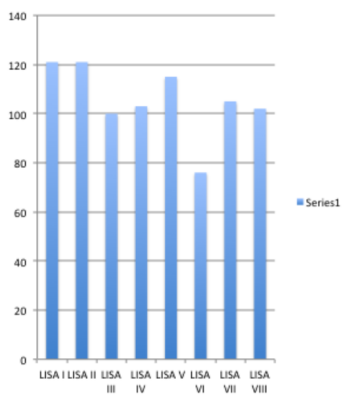

Figure 1. Location and registrant numbers by conference

\section{LISA attendees}

To investigate the attendance at the LISA conferences, I compiled spreadsheets listing the names and the country affiliation for each attendee. I also developed a spreadsheet for each conference, 


$\begin{array}{ll}\text { Argentina (5) } & \text { Italy (32) } \\ \text { Australia (5) } & \text { Japan (6) } \\ \text { Austria (3) } & \text { Korea (2) } \\ \text { Bangladesh (1) } & \text { Malaysia (2) } \\ \text { Belgium (3) } & \text { Mexico (6) } \\ \text { Brazil (1) } & \text { Morocco (1) } \\ \text { Canada (8) } & \text { Netherlands (10) } \\ \text { Chile (5) } & \text { Nigeria (1) } \\ \text { China (8) } & \text { Norway (2) } \\ \text { Czech Republic (9) } & \text { Pakistan (1) } \\ \text { Czechoslovakia (2) } & \text { Poland (6) } \\ \text { Democratic Republic of Congo (1) } & \text { Russia (5) } \\ \text { Denmark (4) } & \text { South Africa (7) } \\ \text { Estonia (1) } & \text { Spain (15) } \\ \text { Finland (3) } & \text { Sweden (3) } \\ \text { France (66) } & \text { Switzerland (6) } \\ \text { Georgia (2) } & \text { Ukraine (6) } \\ \text { Germany (41) } & \text { United Arab Emirates (1) } \\ \text { Greece (1) } & \text { United Kingdom (27) } \\ \text { Hungary (5) } & \text { USA (162) } \\ \text { India (47) } & \text { USSR (2) } \\ \text { Indonesia (2) } & \text { Vatican City (1) } \\ \text { Ireland (1) } & \\ \text { Israel (1) } & \end{array}$

Figure 2. Alphabetical list of participants by country: number of participants from each country listed in parantheses.

followed by a master list of all conference attendees, which I annotated to include the number of conferences each person had attended and specifically which conferences each person had attended. All of the LISA conference proceedings are online and can be accessed from the LISA website http://www.eso.org/sci/libraries/lisa.html maintained by Uta Grothkopf. When available I used the printed participant list from each volume of the conference Proceedings; if there was not a participant list, I used the list available on the website of the meeting.

In all there have been 843 people registered for the LISA conferences. 530 individuals have attended one or more LISA meetings. Not one person has attended all eight LISA meetings. Six individuals have attended LISA II through LISA VIII-Monique Gomez (Spain); Uta Grothkopf (Germany); Jane Holmquist (USA); Maria Elena Jimenez (Mexico); Soizick Lesteven (France) and Francesca Martines (Italy).

Attendees of the various LISA meetings have come from 44 countries from around the world. (See figure 2 for an alphabetical list by country and figure 3 for a map depicting the various countries from which LISA participants have come.)

Since one of the main goals of the LISA conferences is to have representation from astronomical communities around the world, the map shows that the conferences have indeed been truly international. The fact that the six individuals who have attended seven of the eight LISA conferences came from six different countries is also an indication of the international scope of LISA. Not surprisingly there is increased local attendance at each conference.

\section{PAM Survey}

As a member of the PAM Division, I am able to access a membership listing for the division. As a first step in surveying astronomy librarians, a list of 10 questions was developed and sent to PAM Division members who self-identified as astronomy librarians. The 10 questions were: 
Countries represented at LISA conferences

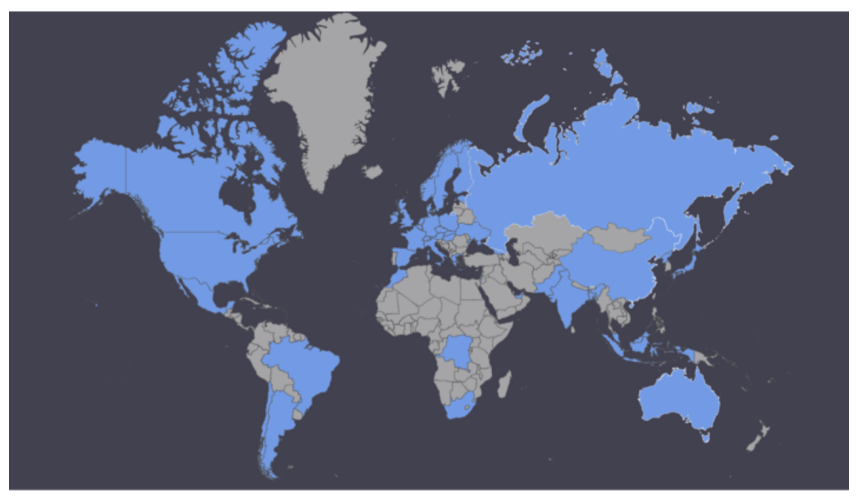

From amcharts.com

Figure 3. Blue shaded areas of map depict countries represented at LISA conferences.

1. What is your job title?

2. Regardless of your official job title, do you consider yourself an "astronomy librarian?" If not, what other title would you give yourself?

3. Please list any additional subject areas that you are responsible for:

4. What is the highest level of education you have completed?

5. What was your major in college?

6. What type of organization do you work in?

7. What are your major responsibilities in your position?

8. How do you see your position evolving over the next three years?

9. Are you aware of the Library and Information Services in Astronomy (LISA) or the IAU Working Group of Information Professionals meetings?

10. One of the goals of my research is to develop a listing of astronomy librarians. If you would like to be included in this list, please provide the information below:

Question 7 had a list of topics from which the respondent could choose answers and a section to add more responsibilities. Question 9 had a list of answers which would indicated whether or not the respondent was aware of the meetings and if they had attended. The other questions were open-ended. Thirty-one people out of the fifty-three people who were sent the survey completed it.

While this was not a large sample, some of my initial findings support some assumptions that I had made about astronomy librarians. Some general findings about astronomy librarians from this short survey:

- Very few librarians have the job title of astronomy librarian 
- Very few librarians cover only astronomy: 22\% also covered physics; $13 \%$ math; $9 \%$ chemistry; $6 \%$ computer science; $5 \%$ engineering; $4 \%$ earth and planetary sciences and about 30 other disciplines including nursing, nutrition, robotics and general science

- $67 \%$ have a master's degree in library science as his/her highest degree

- $58 \%$ have a bachelor's degree in the sciences; $16 \%$ in history, $16 \%$ in literature

- Major responsibilities include reference work, teaching/training, researching and bibliography maintenance

- expected changes upcoming in the next three years

- digital assets management

- building digital archives

- helping faculty demonstrate funding requirements

- scholarly communication

- bibliometrics

- disappearing library space

- digital librarianship

- STEM data

- $75 \%$ were aware of the LISA meetings

- $29 \%$ were aware of the IAU Working Group on Information Professionals

These preliminary results lead me to conclude that the topics being covered in the LISA conferences are relevant to the future of astronomy librarianship and that the astronomy librarian community could do a better job of informing its members of groups and conferences that might be helpful to individuals. While the results of this short survey showed that traditional library tasks such as cataloging and bibliography and reference work will continue to be part of the profession, there is also awareness that some additional duties have not always been traditional librarian skills.

\section{Future study}

In furthering the research necessary to write the white paper for the IAU, I will continue to research groups such as PAM Division members and LISA participants for insights into the profession. In the future I may ask LISA and IAU Working Group meeting participants to identify themselves as scientist, librarian, editor, etc. so that we can find out if the collaborations that we are hoping to develop are already taking place or if we need to do more outreach.

If you have any interest in pursuing the topic of astronomy librarianship in the future, I would be happy to have collaborators. I welcome any feedback or contributions for the white paper.

Long live LISA!

\section{Acknowledgments}

I would like to thank Jill Lagerstrom, former Chief Librarian at the Space Telescope Science Institute, for her ideas which led to this paper and for her input into the questionnaire. 


\section{References}

[1] http://www.eso.org/sci/libraries/lisa.html

[2] B.G. Corbin, U. Grothkopf (2006): LISA ? The Library and Information Services in Astronomy conferences, in Organizations and strategies in astronomy (OSA), vol. 7, A. Heck (ed.), Springer, Dordrecht, ISBN 1-4020-5300-2, p. 285-306

[3] U. Grothkopf, F. Murtagh, C. Birdie, M. Bishop, L. Bobis, D.J. Coletti, B.G. Corbin, M. Gomez, H. Naimova, Division XII / Commission 5 / Working Group Libraries, in Transactions of the International Astronomical Union, Series A (2009), Vol. 27, p. 363-365, doi:10.1017/S174392130802588X

[4] http://pam.sla.org 